\title{
Risk Factors Associated with Prevalence of Bovine Brucellosis in Milk from Tamil Nadu, India
}

\author{
V. Naveen Kumar ${ }^{1 *}$, M. Vijaya Bharathi ${ }^{1}$ and K. Porteen ${ }^{2}$ \\ ${ }^{1}$ Department of Veterinary Preventive Medicine, ${ }^{2}$ Department of Veterinary Epidemiology and \\ Public Health, Madras Veterinary College, Tamil Nadu Veterinary and Animal Sciences \\ University, Chennai - 600 007, Tamil Nadu, India \\ *Corresponding author
}

\section{A B S T R A C T}

Keywords

Brucella, milk, prevalence, risk factors and Tamil Nadu.

Article Info

Accepted: 26 June 2017 Available Online: 10 July 2017
Brucellosis is a contagious and reproductive disease of animals mainly caused by Brucella abortus, B. melitensis, B. suis and B. canis. Diagnosis and identification of associated risk factors in brucellosis is important in devising an effective control strategy. This study is mainly focused to find out the prevalence and assessment of risk factors in lactating cows for bovine brucellosis from eleven districts of Tamil Nadu. A total of 483 milk samples were collected and subjected into Milk Ring Test (MRT) and milk Enzymatic Linked Immunosorbent Assay (m-ELISA), which revealed that 4.35 and 5.80 per cent of the samples were found to be positive by MRT and m-ELISA respectively. Various epidemiological determinants viz., age, breed and clinical history correlation with prevalence rate were assessed. Crossbred cattle, cattle with more than seven years of age and aborted history animals have recorded more prevalence of brucellosis. This manuscript concludes that routine screening, proper diagnosis and correction of identified risk factors will be more useful in devising appropriate disease control programme from the study area.

\section{Introduction}

Brucellosis is one of the highly contagious, zoonotic diseases of animals characterized by abortion in last pregnancy, weak calf, retained fetal membranes, repeat breeding and reduced milk production.

In India, brucellosis was first reported in 1942, and now it is endemic in all over the country (Renukaradhya et al., 2002). In India, brucellosis is mainly transmitted to humans by ingestion of infected milk, contact with infected materials and laboratory infections. In general, milk is a major source of Brucella infection to humans (OIE, 2009).
There is no single test is confirmatory in brucellosis diagnosis due to various demerits of conventional, serological and molecular tests. Hence, a minimum of two standard tests were warranted to find out the true status of animals with brucellosis. For screening of lactating animals, milk is a suitable sample for diagnosis of brucellosis. Brucellosis diagnosis in milk sample can be achieved by directly antigen detection methods (culture, polymerase chain reaction) and indirectly antibody detection methods (milk ring test and milk enzymatic linked immunosorbent assay) (OIE, 2009 and Al-Majali et al., 2009). 
However, in Tamil Nadu there are only limited studies on risk factors assessment in bovine brucellosis diagnosis.

This paper is mainly focused to find out the (i) prevalence of bovine brucellosis (ii) identification of associated risk factors in bovine brucellosis from eleven districts of Tamil Nadu.

\section{Materials and Methods}

\section{Study area}

The present study was conducted in selected districts of Tamil Nadu, viz., Erode, Salem, Kancheepuram, Tiruvallur, Tiruvannamalai, Viluppuram, Thiruvarur, Pudukkottai, Virudhunagar, Tirunelveli, Chennai to assess the current status of Brucella infection.

\section{Selection of animals}

Sexually matured cattle were selected randomly from the study area with the history of abortion, retained fetal membrane, repeat breeding, infertility, pregnant and prepubertal anestrus heifers.

\section{Sampling exclusion}

For obtaining better results in prevalence of brucellosis, the mastitis animals and recent history of parturition animals in terms of avoiding colostrum were excluded in sampling of animals.

\section{Milk samples}

Milk samples were collected from 483 cattle. The udder was thoroughly washed and cleaned with potassium permanganate solution (1:1000) and dried with sterile gauze. Teat openings were disinfected with 70 per cent ethyl alcohol.
After discarding the first few drops of milk, approximately $10 \mathrm{ml}$ of milk from each quarter was collected in two sets of sterile screw capped plastic vials $(50 \mathrm{ml})$ and transported on ice to the laboratory.

\section{Milk Ring Test (MRT)}

Milk Ring Tests antigen was obtained from Indian Veterinary Research Institute (I.V.R.I), Izatnagar.

The antigen was stored at $4^{\circ} \mathrm{C}$ until use. The MRT was performed as per OIE, 2009 guidelines.

\section{Milk Enzyme Linked Immunosorbent Assay (m-ELISA)}

The Brucella Antibody ELISA test kit was purchased from SVANOVIR, Sweden, and used for testing 483 milk samples according to manufacturer's guidelines. The samples were run on Svanovir Brucella-Ab ELISA kit and the optical densities (OD) were determined in a micro plate spectrometer (Bio rad) at 450-nm wavelength.

Positive and negative control samples were included in each test.

Interpretation of the results was based on Per cent Positivity (PP) calculations; $\mathrm{PP}$ is calculated by (Test sample or negative control (OD) x 100) / (Positive control (OD)) and results were interpreted as positive for $\mathrm{PP} \geq$ 10 and Negative for PP $<10$ for individual milk samples.

\section{Identification of risk factors}

In this cross sectional study, a standard questionnaire was prepared and all the information's were collected at the time of sampling to identify the risk factors in Brucella infection from lactating animals. 


\section{Results and Discussion}

\section{Prevalence of bovine brucellosis}

In this present study the prevalence of Brucella infection from milk samples were 4.35 per cent by MRT.

These findings were contradicted with Mahato et al., 2004 (35.82 \%) and Junaidu et al., $2011(25.25 \%)$ who found higher prevalence than present study.

In the present study, m-ELISA documented prevalence rate for bovine brucellosis was 5.80 per cent $(28 / 483)$ (Table 1$)$.

This finding is in accordance with Kang'ethe et al., 2000 (4.9\%) whereas Jai Anand, 2005 (15.07 \%) and Salman et al., 2012 (40.8\%) found higher prevalence rate than present study.

On Comparison of MRT and m-ELISA, mELISA showed a higher sensitivity which was also proved by various authors that it might be due to physiological dominance of IgG over $\operatorname{IgA}$ and $\operatorname{IgM}$ in milk (Vanzini et al., (2001).

In this study, apparent prevalence detected by MRT and m-ELISA were significantly agreed which suggests that, MRT can be useful in field level screening and m-ELISA can be utilized as confirmatory diagnosis against brucellosis in lactating cattle (Patel (2007).

\section{Age-wise prevalence of bovine brucellosis}

Age-wise prevalence of Brucella infection from milk samples was assessed. The highest prevalence was noticed in animals above 7 years age groups by various tests (MRT $8.12 \%$ and $\mathrm{m}$-ELISA $-8.12 \%$ ) followed by 4 7 years (MRT $-1.81 \%$ and m-ELISA $5.42 \%$ ) and $2-4$ years (MRT $-1.67 \%$ and $\mathrm{m}$ -
ELISA - 2.50\%) (Table 1). This present study was agreed with Silva et al., 2000, Amin et al., 2005 and Islam et al., 2013.

Low prevalence was noticed in calves when compared to mature and old animals which might be due to passive immunization of calves through feeding of dam's colostrum (Silva et al., 2000).

Sexually matured and adult cattle have increased sex hormones and erythritol which favours the growth and multiplication of Brucella organisms in the adult animals also play a major role in age advances with Brucella infection (Radostits et al., 2010).

\section{Breed-wise prevalence of bovine brucellosis}

In breed-wise prevalence, crossbred cattle were more susceptible than non-descript cattle (Table 1).

These results were agreed with Salman et al., (1984) and Akbarmehr and Ghiyamirad (2011).

The low prevalence in Non-Descript breeds might be due to natural genetic resistant pattern, adoption in field environment and innate immunity (Aulakh et al., 2008).

\section{Association of previous reproductive disorders with prevalence of bovine brucellosis}

In this study the highest prevalence was recorded in aborted animals $(20.51 \%$ and $20.51 \%$ respectively for MRT and m-ELISA) followed by retained fetal membrane (RFM) (4.76\% and $7.14 \%$ respectively for MRT and m-ELISA), unknown history animals (3.22\% and $4.83 \%$ respectively for MRT and mELISA) and other reproductive problems (1.72\% and $2.87 \%$ respectively for MRT and m-ELISA) (Table 2). 
Table.1 Age and breed wise prevalence brucellosis in milking animals by MRT and mELISA

\begin{tabular}{|c|c|c|c|c|c|c|c|c|}
\hline \multirow[b]{2}{*}{$\begin{array}{l}\text { Risk } \\
\text { factors }\end{array}$} & \multicolumn{4}{|c|}{ Age wise prevalence } & \multicolumn{4}{|c|}{ Breed wise prevalence } \\
\hline & 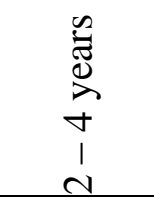 & 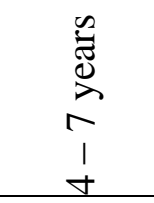 & $\underset{\pi}{\stackrel{0}{\Delta}}$ & Total & $\begin{array}{l}\text { Jersey } \\
\text { cross }\end{array}$ & $\begin{array}{l}\text { Holstein } \\
\text { Friesian } \\
\text { cross }\end{array}$ & $\begin{array}{l}\text { Non- } \\
\text { Descript } \\
\text { breed }\end{array}$ & Total \\
\hline $\begin{array}{l}\text { No. of } \\
\text { samples }\end{array}$ & 120 & 166 & 197 & 483 & 282 & 170 & 31 & 483 \\
\hline MRT & $\begin{array}{c}2 \\
(1.67 \%)\end{array}$ & $\begin{array}{c}3 \\
(1.81 \%)\end{array}$ & $\begin{array}{c}16 \\
(8.12 \%)\end{array}$ & $\begin{array}{c}21 \\
(4.35 \%)\end{array}$ & $\begin{array}{c}13 \\
(4.60 \%)\end{array}$ & $\begin{array}{c}7 \\
(4.11 \%)\end{array}$ & $\begin{array}{c}1 \\
(3.23 \%)\end{array}$ & $\begin{array}{c}21 \\
(4.35 \%)\end{array}$ \\
\hline $\begin{array}{l}\mathrm{m}- \\
\text { ELISA }\end{array}$ & $\begin{array}{c}3 \\
(2.50 \%)\end{array}$ & $\begin{array}{c}9 \\
(5.42 \%)\end{array}$ & $\begin{array}{c}16 \\
(8.12 \%)\end{array}$ & $\begin{array}{c}28 \\
(5.80 \%)\end{array}$ & $\begin{array}{c}18 \\
(6.38 \%)\end{array}$ & $\begin{array}{c}9 \\
(5.29 \%)\end{array}$ & $\begin{array}{c}1 \\
(3.22 \%)\end{array}$ & $\begin{array}{c}28 \\
(5.80 \%)\end{array}$ \\
\hline
\end{tabular}

Table. 2 Prevalence of bovine brucellosis in association with clinical epidemiology

\begin{tabular}{|l|c|l|l|l|l|}
\hline $\begin{array}{l}\text { Previous } \\
\text { reproductive } \\
\text { history }\end{array}$ & $\begin{array}{l}\text { Aborted } \\
\text { animals }\end{array}$ & $\begin{array}{l}\text { Retained } \\
\text { foetal } \\
\text { membranes }\end{array}$ & $\begin{array}{l}\text { Other } \\
\text { reproductive } \\
\text { problems }\end{array}$ & $\begin{array}{l}\text { Unknown } \\
\text { history of } \\
\text { animals }\end{array}$ & $\begin{array}{l}\text { Total no. } \\
\text { of } \\
\text { positives }\end{array}$ \\
\hline $\begin{array}{l}\text { No. of samples } \\
\text { screened }\end{array}$ & 39 & 84 & 174 & 186 & 483 \\
\hline MRT & $\begin{array}{l}8 \\
(20.51 \%)\end{array}$ & $4(4.76 \%)$ & $3(1.72 \%)$ & $6(3.22 \%)$ & $\begin{array}{l}21 \\
(4.02 \%)\end{array}$ \\
\hline m-ELISA & $\begin{array}{c}8 \\
(20.51 \%)\end{array}$ & $6(7.14 \%)$ & $5(2.87 \%)$ & $9(4.83 \%)$ & $28(4.38 \%)$ \\
\hline
\end{tabular}

Table.3 Aborted history animals with prevalence of bovine brucellosis by Various diagnostic tests

\begin{tabular}{|l|c|c|c|c|}
\hline \multirow{2}{*}{$\begin{array}{c}\text { Previous } \\
\begin{array}{c}\text { reproductive } \\
\text { history }\end{array}\end{array}$} & III trimester & II trimester & I trimester & Total No. of Positives \\
\cline { 2 - 5 } & 16 & 12 & 11 & 39 \\
\hline $\begin{array}{l}\text { No. of samples } \\
\text { screened }\end{array}$ & $5(31.25 \%)$ & $3(25.00 \%)$ & 0 & $8(20.51 \%)$ \\
\hline MRT & $6(37.50 \%)$ & $2(16.67 \%)$ & 0 & $8(20.51 \%)$ \\
\hline m-ELISA &
\end{tabular}

This result were concurred with Bachh et al., 1988, Isloor et al., 1998 and Aulakh et al., 2008 whereas Dhand et al., (2005) in Punjab also recorded higher prevalence of brucellosis in animals with a history of abortion $(33.87 \%)$ than in those without such a history $(11.63 \%)$. It obviously concluded that the Brucella is the major etiological agent for abortion in farm animals. Present findings were correlated with high prevalence in unknown history of animals which might be due to lack of appropriate diagnostic facility at field level and screening of animals for brucellosis prior to purchase.

In this study different stages of abortion with its prevalence of bovine brucellosis were analysed, among the three trimesters, high prevalence was recorded in animals with third trimester abortion $(31.25 \%$ and $37.50 \%$ 
respectively for MRT and m-ELISA), followed by second trimester $(25.00 \%$ and $16.67 \%$ respectively for MRT and m-ELISA) and first trimester aborted animals $(0 \%$ and $0 \%$ respectively for MRT and m-ELISA) (Table 3). This findings almost coincide with Islam et al., 2013 reported that, the overall seroprevalence of brucellosis in third semester abortion due to brucellosis was higher $(57.14$ $\%)$ than second (17.58\%) and first (1.09\%) trimester abortion animals. High prevalence of abortion due to brucellosis in this study might be due to uterine environment and erythritol sugar facilitates a condition for the growth of Brucella bacteria leads a severity of disease over the third trimester of pregnancy (Gul and Khan, 2007).

The present study reported that crossbred cattle, cattle more than seven year and aborted animals are at high risk of acquiring brucellosis from the study area. This manuscript concludes that, proper screening, correction of identified risk factors and elimination of infected animals by using confirmatory test which will be useful in reduce the incidence of bovine brucellosis from the study area.

\section{Acknowledgements}

The authors were grateful and sincerely thank Dr. K. Kulasekar, Professor, Department of Veterinary Obstetrics and Gynaeocology, Madras Veterinary College, Chennai for great help and kind co-operation for collection of samples in the infertility camp conducted in study areas and also would like to thank Dr. C. Balachandran, Dean, Madras Veterinary College, Chennai, for the facilities granted to carry out the work.

\section{References}

Akbarmehr, J., and Ghiyamirad, M. 2011. Serological survey of brucellosis in livestock animals in Sarab City (East
Azarbayjan province), Iran. African Journal of Microbiology Research, 5(10): 1220-1223.

Al-Majali, A.M., A.Q. Talafha and Ababneh, M.M. 2009. Seroprevalence and risk factors for bovine brucellosis in Jordan. Journal of Veterinary Science, 10(1): 6165.

Amin, K.M.R., M.B. Rahman, M.S. Rahman, J.C. Han, J.H. Parkand and Chae, J.S. 2005. Prevalence of Brucella antibodies in sera of cows in Bangladesh. Journal of Veterinary Science, 6: 223-226.

Aulakh, H.K., P.K. Patil, S. Sharma, H. Kumar, V. Mahajan and Sandhu, K.S. 2008. A Study on the epidemiology of bovine brucellosis in Punjab (India) using Milk-ELISA. Acta Veterinaria Brno, 77: 393-399.

Bachh, A.S., M.A. Nowsheri, A. Rashidm, A.K. Raina and Wani, S. 1988. Seroprevalence of brucellosis in exotic cattle in Kashmir. Indian Journal of Comparative Microbiology, Immunology and Infectious Diseases, 9: 23-27

Dhand, N.K., S. Gumber, B.B. Singh, Aradhana, M.S. Bal, H. Kumar, D.R. Sharma, J. Singh and Sandhu, K.S. 2005. A study on the epidemiology of brucellosis in Punjab (India) using survey toolbox. Scientific and Technical Review of the Office International des Epizooties, 24(3): 879-885.

Gul, S.T. and Khan, A. 2007. Epidemiology and epizootology of brucellosis. A review. Pakistan veterinary journal, 27: 145-151.

Islam, U.M.R., M.P. Gupta, G.Filia, P.K. Sidhu, T.A.Shafi, $\quad$ S.A.Bhat, S.A.Hussain and Mustafa, R. 2013. Sero-epidemiology of brucellosis in organized cattle and buffaloes in Punjab (India). Advances in animal and veterinary sciences, 1(3): 5-8.

Isloor, S., G.J. Renukaradhaya and Rajasekhar, 
M. 1998. A serological survey of bovine brucellosis in India. Scientific and Technical Review of the Office International des Epizooties, 17(3): 781785.

Jai Anandh. M., 2005. Current status of Bovine Brucella abortus infection in selected districts of Tamil Nadu. M.V.Sc., Thesis submitted to the Tamil Nadu Veterinary and Animal Sciences University, Chennai.

Junaidu, A.U., S.I. Oboegbulem and Salihu, M.D. 2011. Serological survey of Brucella antibodies in breeding herds. Scholars Research Library. Journal of microbiology and biotechnology research, 1(1): 60-65.

Kang'ethe, E.K., S.M. Arimi, A.O. Omore, J.J. McDermott, J.G. Nduhiu, J.K. Macharia and Githua, A. 2000. The prevalence of antibodies to Brucella abortus in marketed milk in Kenya and its public health implications. Paper prepared for oral presentation at the third All Africa Conference on Animal Agriculture, pp.1-4.

Mahato, G., K. Sharma and Mahanta, P.N. 2004. Comparative evaluation of serological tests for detection of brucellosis in bovine. Indian Journal of Veterinary Medicine, 24: 46.

OIE, 2009. Office Internationale des Epizooties. Manual of Standards for Diagnostic Tests and Vaccines, $6^{\text {th }}$ ed. France, OIE Press, pp. 389-428.

Patel, T.J., 2007. Serological, cultural and molecular detection of Brucella infection in bovines including quantification in milk by real-time PCR M.V.Sc., Thesis submitted to the Anand Agricultural University, Gujarath, India. Radostits, O.M., C.C. Gay, K.W. Hinchliff and Constable, P.D. 2010. In: A Medicine textbook of diseases of cattle, horses, sheep, pigs and goats, $10^{\text {th }}$ ed. W. B. Saunder. Co., United Kingdom.

Renukaradhya, G.J., S. Isloor and Rajasekhar, M. 2002. Epidemiology, zoonotic aspects, vaccination and control/eradication of brucellosis in India. Veterinary microbiology, 90: 183-195.

Salman, A.M.A., A. Hind and Nasri, E.I. 2012. Evaluation of four serological tests to detect prevalence of bovine brucellosis in Khartoum state. Journal of Cell Biology, 6: 140-143.

Salman, M.D., M.E. Margaret and Hird, D.W. 1984. Epidemiology of bovine brucellosis in the Mexicali valley, Mexico: Data gathering and survey results. American journal of veterinary research, 45(8): 1561-1566.

Silva, I., A. Dangolla and Kulachelvy, K. 2000. Seroepidemiology of Brucella abortus infection in bovids in Sri Lanka. Preventive veterinary medicine, 46: 51-59.

Vanzini, V.R., N.P. Aguirre, B.S. Valentini, S. Torioni de Echaide, M.D. Lugaresi, L. Marchesino and Nielsen, K. 2001. Comparison of an indirect ELISA with the Brucella milk ring test for detection of antibodies to Brucella abortus in bulk milk samples. Veterinary microbiology, 82: 55-60.

\section{How to cite this article:}

Naveen Kumar, V., M. Vijaya Bharathi and Porteen, K. 2017. Risk Factors Associated with Prevalence of Bovine Brucellosis in Milk from Tamil Nadu. Int.J.Curr.Microbiol.App.Sci. 6(7): 2604-2609. doi: https://doi.org/10.20546/ijcmas.2017.607.367 